\title{
Cleavage Specificity of Chloroplast and Nuclear tRNA 3'-Processing Nucleases
}

\author{
ABRAHAM OOMMEN, $\dagger$ XINQIANG LI, AND PETER GEGENHEIMER* \\ Departments of Botany and Biochemistry and Molecular Genetics Program, University of Kansas, 3038 Haworth Hall, \\ Lawrence, Kansas 66045-2106
}

Received 12 April 1991/Accepted 5 November 1991

\begin{abstract}
tRNAs in eukaryotic nuclei and organelles are synthesized as precursors lacking the $3^{\prime}$-terminal CCA sequence and possessing $5^{\prime}$ (leader) and $3^{\prime}$ (trailer) extensions. Nucleolytic cleavage of the $3^{\prime}$ trailer and addition of CCA are therefore required for formation of functional tRNA $3^{\prime}$ termini. Many chloroplast tRNA genes encode a $\mathrm{C}$ at position 74 which is not removed during processing but which can be incorporated as the first base of the CCA $\mathrm{CH}_{\text {H }}$ terminus. Sequences downstream of nucleotide 74, however, are always removed. Synthetic yeast pre-tRNA ${ }^{\text {Phe }}$ substrates containing the complete $\mathrm{CCA}_{\mathbf{7 4}-76}$ sequence were processed with crude or partially purified chloroplast enzyme fractions. The 3 '-extended substrates (tRNA-CCA-trailer) were cleaved exclusively between nucleotides 74 and 75 to give $t R N A-C_{O H}$, whereas a $3^{\prime}$-mature transcript (tRNA-CCA $A_{\mathrm{OH}}$ ) was not cleaved at all. A 5'-, $3^{\prime}$-extended chloroplast tRNA-CAG-trailer was also processed entirely to tRNA-C $\mathrm{C}_{\text {oH }}$. Furthermore, a $5^{\prime}$-mature, $3^{\prime}$-extended yeast pre-tRNA ${ }^{\text {Phe }}$ derivative, tRNA-ACAtrailer, in which $C_{74}$ was replaced by $A$, was cleaved precisely after $A_{74}$. In contrast, we found that a partially purified enzyme fraction (a nuclear/cytoplasmic activity) from wheat embryo cleaved the $3^{\prime}$-extended yeast

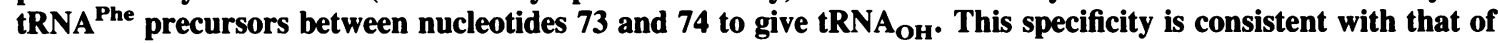
all previously characterized nuclear enzyme preparations. We conclude that (i) chloroplast tRNA $3^{\prime}$-processing endonuclease cleaves after nucleotide 74 regardless of the nature of the surrounding sequences; (ii) this specificity differs from that of the plant nuclear/cytoplasmic processing nuclease, which cleaves after base 73; and (iii) since $3^{\prime}$-mature tRNA is not a substrate for either activity, these $3^{\prime}$ nucleases must require substrates possessing a $3^{\prime}$-terminal extension that extends past nucleotide 76 . This substrate specificity may prevent mature tRNA from counterproductive cleavage by the $3^{\prime}$ processing system.
\end{abstract}

Precursor tRNA transcripts contain extensions at their $5^{\prime}$ and $3^{\prime}$ termini whose removal is an essential step in formation of functional mature tRNA molecules $(11,18,27)$, since it is to the tRNA's 3 '-terminal adenosine residue that amino acids are esterified during protein biosynthesis. Maturation of tRNA precursors requires at least two nucleolytic events: cleavage of the $5^{\prime}$ leader segment by the endonuclease RNase $P(11,26,35,44)$ and removal of the $3^{\prime}$ trailer sequences by endo- or exonucleases $(4,8,12,14,15,19,23$, $28,39,41,47)$. In addition, precursor tRNAs in eukaryotic nuclei and organelles do not contain the sequence -C-C-Acorresponding to the $3^{\prime}$ terminus of mature tRNA (reviewed in references 10 and 11 ). This sequence occupies positions 74 to 76 from the first base of the mature tRNA in the standardized numbering scheme (38). These crucial residues are added posttranscriptionally by the enzyme CTP(ATP):tRNA nucleotidyltransferase (reviewed in references 9 and 10). A generalized tRNA $3^{\prime}$ maturation system could thus comprise up to three different activities: a $3^{\prime}$ endonuclease, a $3^{\prime}$ exonuclease, and nucleotidyltransferase. The participation of auxiliary factors is not precluded.

Despite the importance of $3^{\prime}$ processing in tRNA biosynthesis, little is known about this reaction in eukaryotes, and the mechanisms of substrate recognition remain ill defined. One key question of biological importance is whether (and how) the cell can differentiate between a tRNA which is $3^{\prime}$ mature (lacking a $3^{\prime}$ extension and containing CCA in

\footnotetext{
* Corresponding author.

$\dagger$ Present address: Plant Biology Division, The Samuel Roberts Noble Foundation, P.O. Box 2180, Ardmore, OK 73402-2180.
}

positions 74 to 76 ) and one which must be processed (containing a $3^{\prime}$ extension and/or other sequences at bases 74 to 76). First, must the $3^{\prime}$ extension exceed a certain length before the pre-tRNA is recognized as a substrate? Second, is the $3^{\prime}$ maturation system conservative? That is, if the distribution of nucleotides at the $3^{\prime}$ ends of tRNA genes is random, some genes will be followed by part or all of a -C-C-A- stretch; does the maturation system then remove only those nucleotides which are not part of a CCA sequence and fill in the rest?

Eukaryotic tRNA $3^{\prime}$-end formation. In most well-characterized eukaryotic tRNA processing systems, the $3^{\prime}$ cleavage enzyme is an endonuclease; this has been conclusively demonstrated in extracts of human $(1,46)$, Xenopus laevis $(6,16,23)$, and Drosophila (14) cells, mitochondria from rat liver (28) and yeast (7) cells, and spinach chloroplasts (44). Only in yeast nuclei are some tRNA trailers known to be removed by the action of a $3^{\prime}-5^{\prime}$ exonuclease $(12,33)$. The tRNA $3^{\prime}$ endonucleases from human, $X$. laevis, and Drosophila cells and from yeast and rat liver mitochondria are specific for 5'-mature forms of those pre-tRNAs which were tested $(6,7,14,28,46)$. In general, however, it is likely that a requirement for $5^{\prime}$-mature substrates is not absolute and that the order of $5^{\prime}$ and $3^{\prime}$ cleavages may be different for different pre-tRNAs $(30,36$; discussed in reference 7$)$.

Nuclear and organellar pathways are distinctly different from those in eubacteria. The best-characterized bacterial tRNA $3^{\prime}$ maturation pathway is that of Escherichia coli $\operatorname{tRNA}^{\mathrm{Tyr}}(4,39$; reviewed in reference 18$)$. (In $E$. coli, all tRNA genes encode the terminal $\mathrm{CCA}_{74-76}$ sequence [13].) Initial endonucleolytic cleavage occurs 7 nucleotides (nt) downstream of base $A_{76}$ (39). Subsequent trimming by the 
exonuclease RNase D exposes the mature CCA terminus (8, 47).

Neither in chloroplasts (see below) nor in mitochondria is there yet evidence for a comparable processing pathway, nor is there evidence for enzymes with comparable specificities. During processing of yeast mitochondrial pre-tRNA in a homologous extract, an endonuclease makes a single cleavage precisely between nucleotides 73 and 74 . The products are a 5'-phosphorylated trailer RNA and a 3'-hydroxylterminated tRNA to which CCA residues can subsequently be added (7). In rat liver mitochondria, tRNA 3 ' processing is also accomplished by an endonuclease (28). When the substrate was a bacterial pre-tRNA ${ }^{\text {Tyr }}$ containing a complete $-\mathrm{C}_{74} \mathrm{C}_{75} \mathrm{~A}_{76}$ - block, the majority of processed tRNAs terminated equally after $A_{76}$ or $C_{74}$ and a minority terminated after $A_{73}$ (28). These termini could have been produced by a processing pathway similar to that in $E$. coli and consisting of endonuclease cleavage after $A_{76}$ followed by exonuclease trimming. On the other hand, the results could be interpreted (28) as evidence that the rat liver mitochondrial endonuclease normally cleaves after $\mathrm{A}_{73}$ or $\mathrm{C}_{74}$, but that it recognizes the presence of a complete CCA sequence and attempts to cleave after $\mathrm{A}_{76}$. Interestingly, a minor $\mathrm{tRNA}$ endonuclease activity in yeast mitochondrial extracts can be separated from the major activity. This minor activity cleaves between nucleotides 76 and 77 , which is one of the sites cleaved by the rat liver mitochondrial activity.

Chloroplast tRNA $3^{\prime}$ maturation. tRNA $3^{\prime}$ processing in cellular organelles is noteworthy because the endonucleolytic nature of the activities and the reaction pathways involved resemble those of nuclear systems more closely than those of the eubacterial progenitors of the mitochondrion and chloroplast. tRNA processing pathways have been characterized in chloroplasts of several plants $(19,22,30,44$, 45) and of Euglena gracilis (20). Leader sequences are removed by an RNase P-like endonuclease which has been partially characterized (44). More uncertainty exists concerning $3^{\prime}$ maturation mechanisms. In the chloroplast, as in the nucleus, tRNA genes generally do not encode the entire terminal CCA sequence, and the bases at positions 74 to 76 are essentially random (10; see Results). Only one sequenced chloroplast tRNA gene, encoding tRNA ${ }^{\text {Gly }}$ in wheat, contains a complete CCA sequence (34). Many chloroplast tRNA genes do, however, encode one or two C's in positions 74 and 75 which could be utilized as part of the mature tRNA $\mathrm{CCA}_{\mathrm{OH}}$ terminus (e.g., reference 40; see Results). An important question, then, is whether the $3^{\prime}$ maturation system can recognize the presence of these partial or complete CCA sequences in $3^{\prime}$-extended tRNA precursors and remove only those bases which cannot be incorporated into a mature $\mathrm{CCA}_{\mathrm{OH}}$ terminus.

We previously determined that during processing of $5^{\prime}-$, $3^{\prime}$-extended chloroplast pre-tRNA ${ }^{\text {Phe }}$ in an in vitro system from spinach chloroplasts, the $3^{\prime}$ extension is removed by an endonuclease (44). RNA fingerprint analysis of the released trailer segment demonstrated that it was produced by precise endonucleolytic cleavage between nucleotides 74 and 75 . Cleavage occurred $5^{\prime}$ to the phosphodiester bond phosphate, generating 5'-phosphorylated trailer RNA and 3'-hydroxylterminated tRNA-C ${ }_{74-O H}(44)$. This 3 '-hydroxyl was a primer for tRNA nucleotidyltransferase-mediated addition of the remainder of the CCA sequence. The spinach chloroplast endonuclease preferentially cleaves chloroplast tRNA ${ }^{\text {Phe }}$ which is $5^{\prime}$ mature $(44,45)$ but might cleave other pre-tRNAs which are $5^{\prime}$ extended (30).

This initial finding suggested that the tRNA $3^{\prime}$ maturation system was conservative in that it recognized the presence of a $\mathrm{C}$ at position 74 which could be incorporated into mature tRNA. Thus, if nucleotide 74 were $C$, it was retained and only C-A was added. However, if position 74 were a nucleotide other than cytidylate, it would have to be removed so that a complete C-C-A sequence could be added. This could be accomplished by a second endonuclease cleaving at base 73 or by cleavage at base 74 followed by exonuclease action. In this study, we investigated whether the terminal maturation system could directly recognize any additional bases of the C-C-A sequence. To accomplish this, we first prepared substrates containing an intact C-C-A domain and either no additional $3^{\prime}$ extension or a further $3^{\prime}$ extension of $5 \mathrm{nt}$ (giving a total $3^{\prime}$ extension of $8 \mathrm{nt}$ ). Processing of these substrates was compared with cleavage of an authentic chloroplast pre-tRNA lacking $\mathrm{C}_{75}$ and containing an additional 14-nt $3^{\prime}$ extension. Second, we prepared a substrate in which $\mathrm{C}_{74}$ had been replaced by $A$. The site of $3^{\prime}$ cleavage was determined by $5^{\prime}$-end analysis of the released $3^{\prime}$ trailer RNA. We further compared the point of cleavage in these substrates by the chloroplast enzyme with that of a nuclear/cytoplasmic activity from wheat embryo.

\section{MATERIALS AND METHODS}

Pre-tRNA substrates. Plasmid pNBPhe (pT72-NBPhe) has been described previously (44); it encodes maize chloroplast pre-tRNA ${ }^{\text {Phe }}$ behind a phage $\mathrm{T} 7$ promoter. T7 transcription of BamHI-digested pNBPhe generates a 5'-, 3'-extended precursor tRNA which we call pNBPhe/BamHI; its sequence is shown as precursor II in reference 44. Plasmid p67YF0 (37) was obtained from O. C. Uhlenbeck. It contains a synthetic gene, YF0, encoding yeast (Saccharomyces cerevisiae) tRNA ${ }^{\text {Phe }}$ plus an additional C-C-A, corresponding to the mature $3^{\prime}$ terminus, which is not present in the native gene (37). 5'-mature transcripts are synthesized with T7 RNA polymerase, whereas 5'-extended precursors are generated with SP6 RNA polymerase.

Plasmid pUC19-YF0A74 contains a gene identical to YF0 except that base 74 has been changed from $\mathrm{C}$ to $\mathrm{A}$. YF0A74 was produced by amplification of the $\mathrm{YF0}$ region in plasmid p67YF0, using two synthetic primers: left, YF0.L1 (5'-GGA ATT GCT GCA GTA ATA CGA CTC AC, positions - 30 to -5 with respect to the start of mature $t R N A^{\text {Phe }}$ ), and right, YF0-A74.R1 (5'-ACT CTA GAG GÀT CCT GtT GCG AAT TC, positions +90 to +65$)$. Plasmid DNA (20 ng) was amplified with $100 \mathrm{pmol}$ of each primer in $100 \mu \mathrm{l}$ of a mixture containing $10 \mathrm{mM}$ Tris- $\mathrm{HCl}(\mathrm{pH} 8.3), 50 \mathrm{mM} \mathrm{KCl}, 1.5 \mathrm{mM}$ $\mathrm{MgCl}_{2}, 0.001 \%$ gelatin, $0.2 \mathrm{mM}$ each deoxynucleoside triphosphate (dNTP), and $2 \mathrm{U}$ of Ampli-Taq DNA polymerase (Perkin-Elmer-Cetus), for 25 step-cycles of $94^{\circ} \mathrm{C}(1.5$ $\mathrm{min}) / 70^{\circ} \mathrm{C}(1.5 \mathrm{~min}$ with $5 \mathrm{~s}$ of autoextension). The amplified fragment contains the tRNA gene YF0-A74 flanked on the 5' side by a $P$ st I recognition sequence and a T7 phage promoter and on the $3^{\prime}$ side by BamHI and XbaI restriction sites. Amplified DNA was purified by chromatography over a 2-ml column of Bio-Gel P-100 (Bio-Rad) in TE buffer $(10 \mathrm{mM}$ Tris- $\mathrm{HCl}$ [pH 8.0], $1 \mathrm{mM} \mathrm{Na}$. EDTA [pH 8.0]). This fragment was digested with PstI and XbaI; pUC19 vector was similarly digested and further dephosphorylated. Both DNAs were purified on a gel of $1 \%$ SeaPlaque low-meltingpoint agarose (FMC). Gel slices containing vector and insert were melted and mixed, and the DNAs were ligated overnight at $16^{\circ} \mathrm{C}$ and transformed into $E$. coli DH5 $\alpha$. Recombinant clones were screened by direct amplification of bacterial colonies with the original mutagenic primers. One clone 
was selected, and the DNA sequence of its insert was determined.

Plasmid DNA was prepared by a modification of standard protocols $(29,31)$. Cells were lysed by boiling; after acidic phenol-chloroform and chloroform extractions and isopropanol precipitation, plasmid DNA was separated from RNA by chromatography over a $10-\mathrm{ml}$ column of Sepharose CL-2B (Pharmacia) equilibrated with sterile TNE buffer (10 $\mathrm{mM}$ Tris- $\mathrm{HCl}$ [pH 8.0], $200 \mathrm{mM} \mathrm{NaCl}, 1 \mathrm{mM} \mathrm{Na}$. EDTA [pH 8.0]). Plasmid DNA was pooled, precipitated with anhydrous ethanol (IBI), resuspended in TE buffer, and stored at $-20^{\circ} \mathrm{C}$.

Template DNA was digested to completion with Bst $\mathrm{NI}$ (New England Biolabs), BamHI, HindIII, or PvuII under the conditions recommended by the supplier. Reactions were diluted to $200 \mu \mathrm{l}$ with TNE buffer and extracted with phenol-chloroform and then with chloroform. DNA was concentrated by ethanol precipitation and resuspended in TE buffer.

Precursor tRNA substrates, uniformly labeled to a low specific activity, were prepared by in vitro transcription. Typically, $100-\mu$ reaction mixtures contained $40 \mathrm{mM}$ Tris$\mathrm{HCl}\left(\mathrm{pH} \mathrm{8.0)}, 15 \mathrm{mM} \mathrm{MgCl}_{2}, 50 \mathrm{mM} \mathrm{KCl}, 5 \mathrm{mM}\right.$ dithiothreitol (DTT), either $0.1 \mathrm{mg}$ of acetylated bovine serum albumin per $\mathrm{ml}$ or $2 \mathrm{mM}$ spermidine ( $\mathrm{pH} \mathrm{8.0}$ ), $1 \mathrm{mM}$ each $\mathrm{rNTP}$ (from neutralized aqueous stocks), 20 to $50 \mu \mathrm{Ci}$ of each $\left[\alpha-{ }^{32} \mathrm{P}\right]-$ rNTP, $\sim 100 \mu \mathrm{g}$ of linear DNA per $\mathrm{ml}$, and either 1,000 to $1,200 \mathrm{U}$ of T7 RNA polymerase per $\mathrm{ml}$ or 500 to $1,000 \mathrm{U}$ of SP6 RNA polymerase per ml. Transcription was carried out at $40^{\circ} \mathrm{C}$ for $2 \mathrm{~h}$. Transcripts were purified by denaturing gel electrophoresis and eluted by diffusion at $37^{\circ} \mathrm{C}(44)$. RNA substrates were used without further treatment. In other experiments (not shown), we found that 5 '-extended pretRNAs prepared by this method, when used as substrates for RNase $P$ processing, were as active as transcripts which had further been heat denatured and reannealed. Comparison of $3^{\prime}$ cleavage products from substrates containing a triphosphate $5^{\prime}$ terminus (from $\mathrm{T} 7$ transcription) or containing a monophosphate $5^{\prime}$ terminus (as a result of RNase P cleavage of $5^{\prime}$-extended SP6 transcripts) indicated that the presence of a 5' triphosphate did not influence the specificity of tRNA 3' processing.

Enzymes. (i) Chloroplast. Two spinach chloroplast enzyme preparations were used in these studies. The first preparation, called fraction II, is an $\left(\mathrm{NH}_{4}\right)_{2} \mathrm{SO}_{4}$ fraction of chloroplast stromal protein. Some preparations of fraction II were provided by $\mathbf{M}$. J. Wang of this laboratory. This was prepared essentially according to reference 44 (see also reference 21) except that buffer B was omitted after chloroplast lysis. This preparation contains both $5^{\prime}$ (RNase P) and $3^{\prime}$ cleavage activities when assayed on pNBPhe/BamHI transcripts. The second enzyme preparation, called fraction $\mathrm{C}$, is a partially purified fraction also containing both $5^{\prime}$ and $3^{\prime}$ cleavage activities and was provided by $\mathbf{M}$. J. Wang. Fraction C was purified from fraction II $(7.7 \mathrm{ml}, 192 \mathrm{mg})$ by binding to a $50-\mathrm{ml}$ DE-52 cellulose (Whatman) column in buffer F (20 mM Tris- $\mathrm{HCl}$, [pH 8.0], $1 \mathrm{mM} \mathrm{Na}$. EDTA, 15\% glycerol) containing $50 \mathrm{mM} \mathrm{KCl}, 2 \mathrm{mM}$ DTT, $0.1 \%$ Brij-35, and $1 \times$ protease inhibitor mix (44), washing thoroughly with the same buffer, and eluting with the same buffer plus 180 $\mathrm{mM} \mathrm{KCl}$. Fractions containing RNase $\mathrm{P}$ activity also exhibited 3' endonuclease activity as assayed on pNBPhe/BamHI transcripts. These fractions were pooled, adjusted to $50 \mathrm{mM}$ $\mathrm{KCl}$, and applied to a $\sim 20-\mathrm{ml}$ column of Phospho-Spectrogel (Spectrum) equilibrated with buffer $\mathrm{F}$ plus $50 \mathrm{mM} \mathrm{KCl}, 1$ mM DTT, and $1 \times$ protease inhibitors. After washing with this buffer, protein was eluted with $180 \mathrm{mM} \mathrm{KCl}$ in buffer $\mathrm{F}$. Fractions with RNase P activity also contained 3 ' endonuclease activity; these were pooled and concentrated.

(ii) Wheat embryo. During purification of RNase $P$ from wheat embryo (32a), tRNA 3' endonuclease activity copurifies up to and sometimes through the HA-Ultrogel (hydroxylapatite-agarose; Spectrum) step. The preparation used in these experiments had been purified as follows. Wheat germ (Sigma), purified by organic flotation as described previously (17), was homogenized in extraction buffer $(20 \mathrm{mM}$ Tris- $\mathrm{HCl}$ [pH 8.0], $50 \mathrm{mM} \mathrm{KCl}, 1 \mathrm{mM} \mathrm{Na}$. EDTA, $1 \mathrm{mM}$ DTT, 5\% glycerol, $1 \mathrm{mM}$ phenylmethylsulfonyl fluoride, $1 \times$ protease inhibitors). The $14,000 \times g$ supernatant was fractionated with 40 to $60 \%$ saturation (at $0^{\circ} \mathrm{C}$ ) ammonium sulfate. The resultant pellet was resuspended, dialyzed against buffer $F$ plus $50 \mathrm{mM} \mathrm{KCl}$ and $1 \mathrm{mM}$ DTT, and applied to a column of DE- 52 cellulose equilibrated in the same buffer. The RNase $P$ activity eluted with buffer $F$ plus $200 \mathrm{mM} \mathrm{KCl}$ was dialyzed and applied to a column of DEAE-Sephacel (Pharmacia) equilibrated in buffer $\mathrm{F}$ plus $50 \mathrm{mM} \mathrm{KCl}$. RNase P eluted between 120 and $150 \mathrm{mM} \mathrm{KCl}$. The pooled activity was dialyzed into buffer $\mathrm{P}(25 \mathrm{mM}$ potassium phosphate [pH 7], $0.1 \mathrm{mM} \mathrm{Na}$. EDTA, $1 \mathrm{mM}$ DTT, $15 \%$ glycerol) and applied to a column of HA- Ultrogel in the same buffer. RNase $P$ activity eluted around $130 \mathrm{mM} \mathrm{PO}$. When assayed against a 5'-, 3'-extended substrate, one preparation lacked detectable tRNA $3^{\prime}$ cleavage activity while the second did possess $3^{\prime}$-processing activity (32a).

Processing reactions. Cleavage assays were carried out in $20 \mu \mathrm{l}$ of $20 \mathrm{mM}$ Tris- $\mathrm{HCl}(\mathrm{pH} 8.0)-30 \mathrm{mM} \mathrm{NH} \mathrm{Nl}_{2}-2 \mathrm{mM}$ $\mathrm{MgCl}_{2}-5 \%$ glycerol containing 0.1 to $1.0 \mathrm{pmol}$ of $\left[{ }^{32} \mathrm{P}\right] \mathrm{RNA}$ substrate and $15 \mu \mathrm{g}$ of chloroplast fraction II, 0.25 to $0.5 \mu \mathrm{g}$ of fraction $\mathrm{C}$ protein, or 2.4 to $3.0 \mu \mathrm{g}$ of wheat embryo HA-Ultrogel fraction. Some preliminary reactions were also performed in chloroplast processing buffer (44). Reactions were terminated by proteinase $\mathrm{K}$ digestion $\left(15 \mathrm{~min}, 55^{\circ} \mathrm{C}\right)$ and analyzed by electrophoresis on denaturing $10 \%$ polyacrylamide gels $(0.5 \mathrm{~mm}$ thick $)$, all as previously described (44). Some reactions (e.g., those shown in Fig. 2B) were treated by phenol extraction and ethanol precipitation from 2 $\mathrm{M}$ ammonium acetate prior to electrophoresis.

For preparation of substrates for CCA addition, cleavage reactions were scaled up to $100 \mu$ l containing ca. $10 \mathrm{pmol}$ of $\left[{ }^{32} \mathrm{P}\right]$ pre-tRNA and $375 \mu \mathrm{g}$ of fraction II, $6.25 \mu \mathrm{g}$ of fraction $C$ chloroplast enzymes, or $30 \mu \mathrm{g}$ of wheat embryo HAUltrogel pool protein. Reactions were stopped as described above, and products were recovered after electrophoresis on $10 \%$ polyacrylamide gels containing $7 \mathrm{M}$ urea.

CCA addition assays were done in $10 \mu$ l of chloroplast processing buffer (44) with $1.4 \mathrm{mM}$ DTT, $10 \%$ glycerol, 0.1 to $1.0 \mathrm{mM}$ ATP and/or $0.1 \mathrm{mM} \mathrm{CTP}$, ca. 5,000 cpm of 3'-processed tRNA, and ca. $6.25 \mu \mathrm{g}$ of fraction II chloroplast protein diluted, if necessary, with dialysis buffer (44) or 20 $\mathrm{mM}$ Tris- $\mathrm{HCl}$ ( $\mathrm{pH} 8.0)-15 \%$ glycerol. Mixtures were incubated for $30 \mathrm{~min}$ at $37^{\circ} \mathrm{C}$ and then subjected to proteinase $\mathrm{K}$ treatment and gel electrophoresis described as above.

Nucleotide analysis. Two-dimensional fingerprinting of RNase $T_{1}$-generated oligonucleotides using homomix $\mathrm{C} 10$ and analysis of the subsequent $\mathrm{RNase} A$ redigestion products was performed as described in reference 44 and references therein. Oligonucleotide sequences and yields were matched with the DNA sequence of pUC19-YF0A74, using the programs FINGERS and OLIGOS (44). RNase $\mathrm{T}_{2}$ digestions were carried out with $2.5 \mathrm{U}$ of enzyme in $20 \mathrm{mM}$ ammonium acetate for $4 \mathrm{~h}$ at $37^{\circ} \mathrm{C}$. Products were separated on prewashed polyethyleneimine thin-layer plates developed 
with $1.6 \mathrm{M} \mathrm{LiCl}$. Internal markers of $\mathrm{pAp}$ and $\mathrm{pGp}$ were present; the position of $\left[{ }^{32} \mathrm{P}\right] \mathrm{pCp}$ (New England Nuclear) relative to $\mathrm{pAp}$ was determined in a parallel analysis. A detailed summary of the redigestion analysis is available upon request.

Sequence comparisons. Genomic sequences of tobacco and liverwort chloroplasts, and the location and extent of individual tRNA genes, were from published sources $(32,40)$. The rice chloroplast genomic sequence (25) was obtained from the EMBL data base (accession number X15901). Other chloroplast tRNA gene sequences were obtained from release 63.0 of the GenBank data base. The data base was searched for all indexed chloroplast tRNA genes by using SeqAidII software (D. J. Roufa and D. D. Rhoads, Division of Biology, Kansas State University, Manhattan). Only plant genes were considered further.

The locations and extents of tRNA genes were identified from the GenBank or EMBL features table. These gene boundaries did not include the region occupied by CCA in the mature tRNA. The following data base entries contain all of the chloroplast tRNA genes which are followed by one or more bases of the CCA terminus: CHOSXX (rice chloroplast genome), MPOCPCG (liverwort chloroplast genome), MZECPTGF, MZECPTPW, MZECPTRS1, OBECPBPW, PEACPHD, PEACPRP14, PEACPTGRN, PENCPTRNI, SOYCPPSB1, SPICPRGDG, SPICPTGI, TOBCPCG (tobacco chloroplast genome), WHTCPTRN1, and WHTCPTRNW. In comparisons of genes within a single genome, $30 \%$ of tobacco chloroplast tRNA genes encoded $\mathrm{C}_{74}$ (eight genes; $27 \%$ ) or $\mathrm{C}_{74} \mathrm{C}_{75}$ (one gene; $3 \%$ ), as did $20 \%$ of rice chloroplast tRNA genes (four genes with $3^{\prime}-\mathrm{C}$ and two with $\mathrm{CC}$ ) and $10 \%$ of liverwort tRNA genes (two genes with $3^{\prime}-\mathrm{C}$ and one with $\mathrm{CC})$. The genes followed by $\mathrm{C}_{74}$ only, and the fraction of sequences for each tRNA species, were trnI-CAU (four of five genes were followed by CNN), trnR-ACG (four of five), trnH-GUG (four of six), $t r n F-G A A$ (three of five), $t r n G-G C C$ (two of five), trnI-GAU (one of five), and trnfM (one of five). The genes followed by $\mathrm{C}_{74}$ and $\mathrm{C}_{75}$ are trnP-UGG (six of seven sequences contain $\mathrm{CCN}$ ) and $\operatorname{trnS}$-GCU (two of four). Finally, of five trnG-UCC gene sequences, one (in wheat) encodes $\mathrm{CCA}_{74-76}$ and one (in tobacco) encodes $\mathrm{C}_{74}$ only.

A comparable search was conducted for plant nuclear tRNA genes. In addition, sequences of Arabidopsis thaliana genes for tRNA $A_{i}^{\text {Met }}, \operatorname{tRNA}^{\mathrm{Tyr}}, \mathrm{tRNA}_{1,2}^{\text {Phe and 3 }}$, and tRNA ${ }^{\text {Ala }}$ were obtained from references 2,3 , and 42 . Of 15 sequences, 2 , those for Phaseolus vulgaris tRNA ${ }^{\text {Tyr }}$ and tRNA ${ }^{\text {Pro }}$, encode $\mathrm{C}_{74}$ only. GenBank loci examined were PETTGN, PHV PYTRNY, PHVTGP, SOYTGDA, SOYTGMI, SRGTRNG, TOBTRNY[X], and WHTTGNS.

\section{RESULTS}

Chloroplast and nuclear tRNA genes encoding partial CCA sequences. In chloroplasts, tRNA genes are thought not to encode the 3'-terminal C-C-A sequence (e.g., reference 10). We found, however, that many plant chloroplast tRNA genes do encode cytidines at position 74 or at positions 74 and 75, which could serve as the first one or two bases of the mature tRNA's $\mathrm{CCA}_{\mathrm{OH}}$ terminus. We first noticed that the maize chloroplast tRNA ${ }^{\mathrm{Phe}}$ gene, $\operatorname{trn} F-\mathrm{GAA}$, is followed by a $C$ in what would be position 74 of the mature tRNA sequence (43), that is, the first base of the CCA. Cytidine is also found in this position of tobacco chloroplast trnF-GAA (40). (The nomenclature of chloroplast tRNA genes is as described elsewhere [24], specifying the amino acid by the one-letter code and the isoacceptor by the anticodon.) To
TABLE 1. Sequences distal to chloroplast tRNA genes

\begin{tabular}{|c|c|c|c|c|c|c|}
\hline \multirow{2}{*}{ Gene } & \multicolumn{4}{|c|}{$\begin{array}{l}3^{\prime} \text { flanking sequences at } \\
\text { positions } 74-76\end{array}$} & \multicolumn{2}{|c|}{ Total genes examined } \\
\hline & NNN & $\mathrm{CNN}$ & $\mathrm{CCN}$ & CCA & With $C(C)(A)$ & Total \\
\hline $\operatorname{trnF-GAA}$ & 2 & 3 & 0 & 0 & 3 & 5 \\
\hline $\operatorname{trn} G-\mathrm{GCC}$ & 3 & 2 & 0 & 0 & 2 & 5 \\
\hline $\operatorname{trn} G$-UCC & 3 & 1 & 0 & 1 & 2 & 5 \\
\hline $\operatorname{trn} H$-GUG & 2 & 4 & 0 & 0 & 4 & 6 \\
\hline trnI-CAU & 1 & 4 & 0 & 0 & 4 & 5 \\
\hline trnI-GAU & 4 & 1 & 0 & 0 & 1 & 5 \\
\hline $\operatorname{trn} K$-UUU & 2 & 1 & 0 & 0 & 1 & 3 \\
\hline $\operatorname{trnfM}$ & 4 & 1 & 0 & 0 & 1 & 5 \\
\hline $\operatorname{trn} P$-UGG & 1 & 0 & 6 & 0 & 6 & 7 \\
\hline trnR-ACG & 1 & 4 & 0 & 0 & 4 & 5 \\
\hline $\operatorname{trn} S-G C U$ & 2 & 0 & 2 & 0 & 2 & 4 \\
\hline Total & 25 & 21 & 8 & 1 & 30 & 55 \\
\hline $\begin{array}{l}\text { Other genes in } \\
\text { sequenced } \\
\text { genomes }\end{array}$ & 58 & 0 & 0 & $\mathbf{0}$ & $\mathbf{0}$ & 58 \\
\hline All other genes & 56 & 0 & $\mathbf{0}$ & $\mathbf{0}$ & 0 & 56 \\
\hline Total & 139 & 21 & 8 & 1 & 30 & 169 \\
\hline
\end{tabular}

$a$ tRNA genes, other than those listed, in sequenced chloroplast genomes (tobacco, rice, and liverwort).

determine whether more tRNA genes encoded a portion of the CCA domain, we examined the $3^{\prime}$ flanking sequences of all tRNA genes in the chloroplast genomes of tobacco, rice, and liverwort and of all other indexed plant chloroplast tRNA genes in the GenBank data base (see Materials and Methods). We found 30 gene sequences, representing 10 different tRNA species, which in at least one organism encoded part or all of the $3^{\prime} \mathrm{C}-\mathrm{C}$-A terminus. The distribution of these genes is summarized in Table 1 . Overall, 30 of 169 genes examined $(17.8 \%)$ were followed by at least one base of a C-C-A run. Of these, 21 genes (12.4\%) included $\mathrm{C}_{74}$ only, 8 genes $(4.7 \%)$ included $\mathrm{C}_{74}$ and $\mathrm{C}_{75}$ only, and 1 gene $(0.6 \%)$ possessed a complete $3^{\prime}$ CCA flank. These overall frequencies are comparable to those expected if the distribution of nucleotides at each position is random. Interestingly, however, the distribution of $\mathrm{C}_{74}$ and $\mathrm{C}_{75}$ to specific chloroplast tRNA genes is decidedly nonrandom (Table 1). It appears that the sequences at these positions, like those of the tRNA genes themselves, were evolutionarily fixed prior to the divergence internal to the land plants.

In contrast to chloroplast genes, plant nuclear tRNA genes are less likely to encode $\mathrm{C}_{74}$. Most plant nuclear tRNA genes are followed by a thymidylate-rich run corresponding to the oligouridylate RNA polymerase III termination signal. Of 15 plant nuclear tRNA gene sequences examined, only 2 (13.3\%) had cytidylate at position 74 ; none possessed a more extensive CCA domain.

Substrates for tRNA $3^{\prime}$ processing. To investigate the role of specific sequences in 3 '-terminal maturation, we used five substrates. The control chloroplast substrate was a precursor to native maize chloroplast tRNA ${ }^{\text {Phe }}(43)$, which possesses only $\mathrm{C}_{74}$. This precursor is called pC3 or tRNA-CAGtrailer. The test substrates were three precursors to yeast tRNA ${ }^{\text {Phe }}$ which contained a complete $3^{\prime}$-CCA sequence but differed in the length of their $3^{\prime}$-terminal extensions and one substrate which contained a $3^{\prime}$-ACA sequence and a long $3^{\prime}$ trailer. Transcription of plasmid p67YF0 (37; see Materials and Methods) linearized with BstNI, with BamHI, or with HindIII allows synthesis of yeast pre-tRNA ${ }^{\text {Phe }}$ transcripts which are $3^{\prime}$ mature or possess $3^{\prime}$-terminal extensions, 
including the CCA, of 8 or $35 \mathrm{nt}$. Transcription of plasmid pUC19-YF0A74 linearized with $P v u I I$ afforded a substrate with a 3 '-terminal extension of $130 \mathrm{nt}$. The 3 '-mature substrate is designated $\mathrm{Y}$ or tRNA-CCA $\mathrm{OH}_{\mathrm{OH}}$, and the two 3'extended, tRNA-CCA-trailer forms are called Y3B (tRNACCAGGAUC $_{\mathrm{OH}}$ ) and Y3H (tRNA-CCAGGA...26 nt... $\mathrm{GCU}_{\mathrm{OH}}$ ). The A74 mutant is denoted YA74-3P (tRNA-ACAtrailer). The extended acceptor stems of the first four pretRNAs are illustrated in Fig. 1A through D. The mature portion of maize chloroplast pre-tRNA ${ }^{\text {Phe }}$ closely resembles spinach chloroplast tRNA ${ }^{\text {Phe }}$ (5). Figure $1 \mathrm{E}$ shows the sequence of the YF0A74 transcript, tRNA-ACA-trailer. The positions of oligonucleotides resulting from RNase $T_{1}$ digestion are indicated under the sequence. The differences among these tRNA ${ }^{\text {Phe }}$ sequences are noted in Fig. 1F. Although the yeast pre-tRNA transcripts differ in sequence from the chloroplast pre-tRNA, they are similar around the putative site of 3' processing. In fact, except for the absence of $\mathrm{C}_{75}$ in the chloroplast sequence, the yeast and chloroplast tRNA ${ }^{\text {Phe }}$ sequences are identical between positions 71 and 77. We show below that the heterologous substrates are processed to the same $3^{\prime}$ nucleotide as is the maize chloroplast pre-tRNA. The results should thus be generally applicable to chloroplast tRNA processing.

Precursor tRNAs, 5' mature and either $3^{\prime}$ extended or $3^{\prime}$ mature, were synthesized in vitro by transcription with phage T7 RNA polymerase. For the substrates tested here, the $3^{\prime}$-terminal extension is probably comparable to that which exists in vivo. Since the 7- to 8-nt trailer RNA released from our yeast pre-tRNA transcripts is too short for convenient analysis, we do not have direct evidence that this trailer is removed by the same endonuclease (44) which removes the trailer from chloroplast tRNA ${ }^{\text {Phe }}$ rather than by an exonuclease. As demonstrated below, we know that this endonuclease is present and active in the enzyme preparations tested. For simplicity, we use the term $3^{\prime}$ cleavage to refer to either exo- or endonuclease action.

Precise cleavage at $\mathbf{C}_{\mathbf{7 4}}$ by a chloroplast nuclease. Three substrates were tested: $5^{\prime}$-, $3^{\prime}$-extended chloroplast pre-tRNA ${ }^{\text {Phe }}$ (pre-tRNA-CAG-trailer), $3^{\prime}$-extended yeast tRNA ${ }^{\text {Phe }}$ (tRNA-CCA-trailer), and $3^{\prime}$-mature yeast tRNA ${ }^{\text {Phe }}$ (tRNA-CCA $\mathrm{OH}_{\mathrm{OH}}$ ). We processed these tRNAs with crude or with partially purified chloroplast enzyme preparations containing both RNase P and 3' endonuclease. To demonstrate that the results resulted solely from the action of the $3^{\prime}$ endonuclease, we also performed reactions with partially purified RNase P (from wheat embryo, lacking detectable 3' nuclease activity; see Materials and Methods). As seen in Fig. 2A (lanes 1 and 2 versus lanes 3 and 4), RNase $P$ alone does not affect the 3'-extended or 3'-mature yeast tRNAs. When 3'-extended pre-tRNA-CCA-trailer was processed with a partially purified 3 -nuclease-containing fraction from chloroplasts (Fig. 2A, lane 5), the fully processed product was a species which migrated faster than the 76-nt-long tRNA-CCA ${ }_{\mathrm{OH}}$. Subsequent analysis, described below, demonstrated that this product is a 74-nt-long tRNA- $\mathrm{C}_{\mathrm{OH}}$ which results from cleavage of the precursor between nucleotides $\mathrm{C}_{74}$ and $\mathrm{C}_{75}$. When $3^{\prime}$-mature tRNA was treated with the same enzyme fraction (Fig. 2A, lane 6), we were surprised to find that its size was unaltered. This result indicates that mature tRNA is not a substrate for $3^{\prime}$ maturation.

The $3^{\prime}$ cleavage activity previously detected in chloroplast extracts was already known to be an endonuclease which cleaved $5^{\prime}$ of the phosphate following nucleotide $\mathrm{C}_{74}(44)$. We did not know, however, whether the same position would be cleaved in a heterologous substrate. We therefore directly compared $3^{\prime}$ cleavage of yeast $\mathrm{tRNA}{ }^{\text {Phe }}$ with that previously characterized for maize chloroplast pre-tRNA ${ }^{\text {Phe }}$. As shown in Fig. 2A, lane 7, processing of $5^{\prime}-, 3^{\prime}$-extended chloroplast pre-tRNA ${ }^{\text {Phe }}$ with the partially purified fraction $C$ enzyme gave rise to the expected molecules: first, the two products of RNase $P$ cleavage (released $5^{\prime}$ leader and $5^{\prime}$ mature, $3^{\prime}$-extended pre-tRNA intermediate), and second, the product of subsequent $3^{\prime}$ cleavage (tRNA- $\mathrm{C}_{\mathrm{OH}}$ ). The $5^{\prime}-$, $3^{\prime}$-mature chloroplast tRNA ${ }^{\text {Phe }}$ comigrates with the processed yeast tRNA ${ }^{\text {Phe }}$. Yeast nuclear and plant chloroplast tRNA $^{\text {Phe }}$ are thus cleaved at the same position. Further evidence for localization of the cleavage site will be presented below.

Our previous fingerprint analysis of tRNA $3^{\prime}$ cleavage products (44) was carried out on RNAs processed with the initial ammonium sulfate fraction, fraction II. Figure 2B demonstrates that both this fraction and the more purified fraction $\mathrm{C}$ chloroplast enzymes tested in Fig. 2A give identical results. Comparison of lanes 4 and 8 with lane 10 in Fig. 2B shows that both enzyme preparations fail to cleave 3'-mature tRNA-CCA $\mathrm{OH}_{\mathrm{OH}}$. They do process 3'-extended yeast tRNA (lanes 3 and 7) or chloroplast pre-tRNA (lanes 5 and 6) to the same-size product, tRNA- $\mathrm{C}_{\mathrm{OH}}$. Identification of this product is described below.

We also tested 5'-, 3'-extended pre-tRNA ${ }^{\text {Phe }}$ transcribed from plasmid p67YF0 with SP6 RNA polymerase. Terminal cleavage of these substrates (Fig. 5 and data not shown) was identical to that of 5 -mature tRNAs.

Final maturation by sequential addition of CMP and AMP. We located the exact $3^{\prime}$ end of processed tRNA and demonstrated that it was functional by assaying its ability to accept CMP and AMP, thus forming a complete CCA terminus. Fingerprint analysis of 3 '-processed chloroplast or yeast tRNA ${ }^{\text {Phe }}$ does not always retain the RNase $T_{1}$-generated 3'-terminal oligonucleotide $\mathrm{CAC}_{\mathrm{OH}}$. However, if any portion of the terminal $\mathrm{ACCA}_{73-76}$ sequence is present in the product tRNA, it can be regenerated by CTP(ATP):tRNA nucleotidyltransferase (reviewed in references 9 and 10 ). The specificity of tRNA nucleotidyltransferase is such that addition stops after completion of a C-C-A sequence (10). The number of bases added by nucleotidyltransferase is thus an accurate measure of the extent of the 3'-terminal A-CC-A domain prior to addition. Furthermore, transfer RNA species lacking 3'-ACCA are very poor substrates for tRNA nucleotidyltransferase (9). As described below, we found that the processed tRNA could be elongated by just two nucleotides when reincubated with CTP and ATP. Hence only the last two bases (C and A) of the mature tRNA were missing. Our source of nucleotidyltransferase was the activity endogenous in the chloroplast lysate (19). Control experiments were performed to verify that we were assaying specific CCA addition and not a nonspecific terminal transferase activity.

We isolated processed putative tRNA- $\mathrm{C}_{\mathrm{OH}}$, incubated it with CTP and/or ATP in the presence of fraction II chloroplast enzymes, and assayed nucleotide addition by electrophoresis on a denaturing polyacrylamide sequencing gel. The results are shown in Fig. 4A for chloroplast tRNA ${ }^{\text {Phe }}$ and in Fig. 4B for yeast tRNA ${ }^{\text {Phe }}$. In Fig. 4A, two different preparations of fraction II were used for the assays of lanes 2 to 5 and lanes 6 and 7, respectively. The size of the substrate was unaltered during incubation in the absence of nucleotides. For example, a comparison of lanes 1 and 2 of Fig. 4A, or lanes 5 and 6 of Fig. 4B, shows that no terminal nucleotide addition or removal occurred in the absence of added CTP or ATP. Figure 4A, lane 4, and Fig. 4B, lane 2, 
A. Precursor ( $P$ )Y (Yeast)

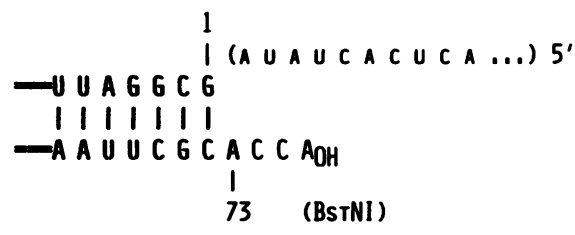

C. Precursor ( $P$ )Y3H

A

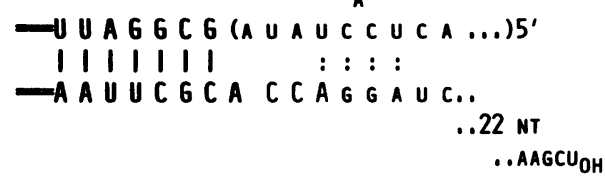

B. Precursor ( $P$ ) Y3B

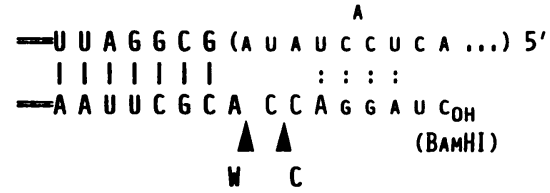

E. Precursor YA74-3P

D. Precursor pC3 (ChLOROPLASt)

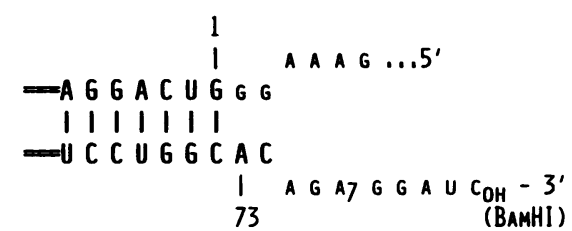

(HINDIII)

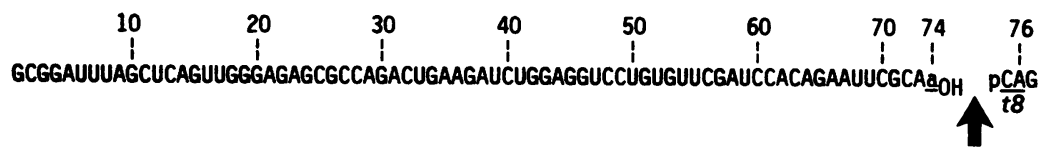

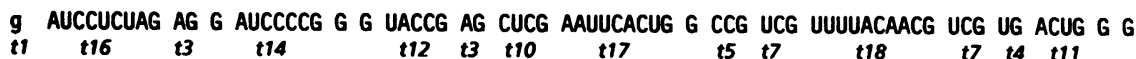

AaAACCCUG G CG UUACCCAACUUAAUCG CCUUG CAG CACAUCCCCCUUUCG CCAG
t15

\section{F. Aligned seouences}

Spinach chl.

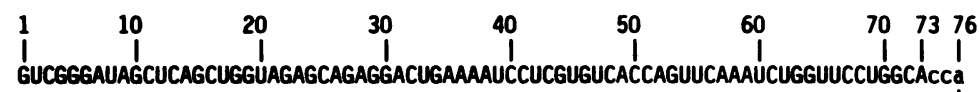

Maize chl.

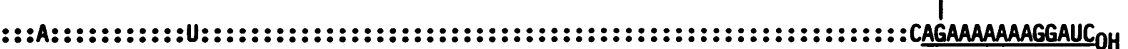

Yeast cyt./synth.

Wheat cyt.

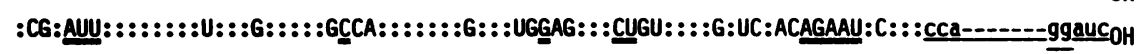

Arabidopsis cyt.

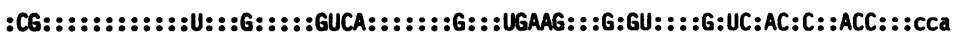

FIG. 1. Structures and sequences of substrates. (A) Substrate $Y: 3^{\prime}$-mature yeast pre-tRNA ${ }^{\text {Phe }}$; (B) substrate Y3B: 8-nt 3'-extended yeast pre-tRNA $^{\text {Phe }}$; (C) substrate $\mathrm{Y} 3 \mathrm{H}$ : 35-nt 3'-extended yeast pre-tRNA ${ }^{\text {Phe }}$; (D) substrate pC3: 5' -, 3'-extended maize chloroplast tRNA ${ }^{\text {Phe }}$. For panels $A$ to $D$, mature-domain nucleotides are in boldface and precursor-specific extensions are in lowercase. The prefix (p) denotes the optional $5^{\prime}$ precursor-specific segment enclosed in parentheses. In panel B, the arrowheads labeled W and C indicate the tRNA $3^{\prime}$ termini generated by wheat embryo and chloroplast enzyme preparations, respectively. (E) Substrate YA74-3P: $3^{\prime}$-extended yeast pre-tRNA ${ }^{\text {Phe }}$ YF0-A74. Construction of the DNA template is described in Materials and Methods. Under the sequence is given the number of each RNase $\mathrm{T}_{1}$-generated oligonucleotide. (F) Similarity among tRNA ${ }^{\text {Phe }}$ sequences from spinach and maize chloroplast and from yeast, wheat, and Arabidopsis cytoplasm. Spinach chloroplast and wheat cytoplasmic sequences are those of the tRNAs; the others are inferred from DNA sequences. The maize chloroplast sequence is clone pT72-NBPhe/Bam HI (44), the yeast gene is clone p67YF0/Bam HI (37), and the A. thaliana sequence is clone P-5-S (3). Nucleotides present in the native gene are shown in uppercase; those derived from vector or from synthetic DNA are in lowercase. The 3' precursor-specific extensions are underlined. Bases marked by colons are identical to the spinach chloroplast $\mathrm{tRNA}^{\text {Phe }}$ sequence. Arabidopsis positions marked with periods are identical to those of wheat cytoplasmic tRNA ${ }^{\text {Phe }}$, and double-underlined yeast nucleotides are those which differ from wheat RNA $^{\text {Phe }}$.

demonstrate that incubation with only CTP resulted in quantitative addition of a single CMP residue. Incubation with CTP plus ATP converted all of the starting material to products one and two bases longer (Fig. 4A, lanes 5 and 7; Fig. 4B, lane 3). These results indicate quantitative addition of CMP followed by substoichiometric addition of AMP. Little if any nucleotide addition was observed with ATP only (Fig. 4A, lane 3; Fig. 4B, lane 4). (In other experiments [not shown], we observed low-level addition of two bases in the presence of ATP alone. Formation of tRNA-C-A-A $\mathrm{AH}_{\mathrm{OH}}$ is 

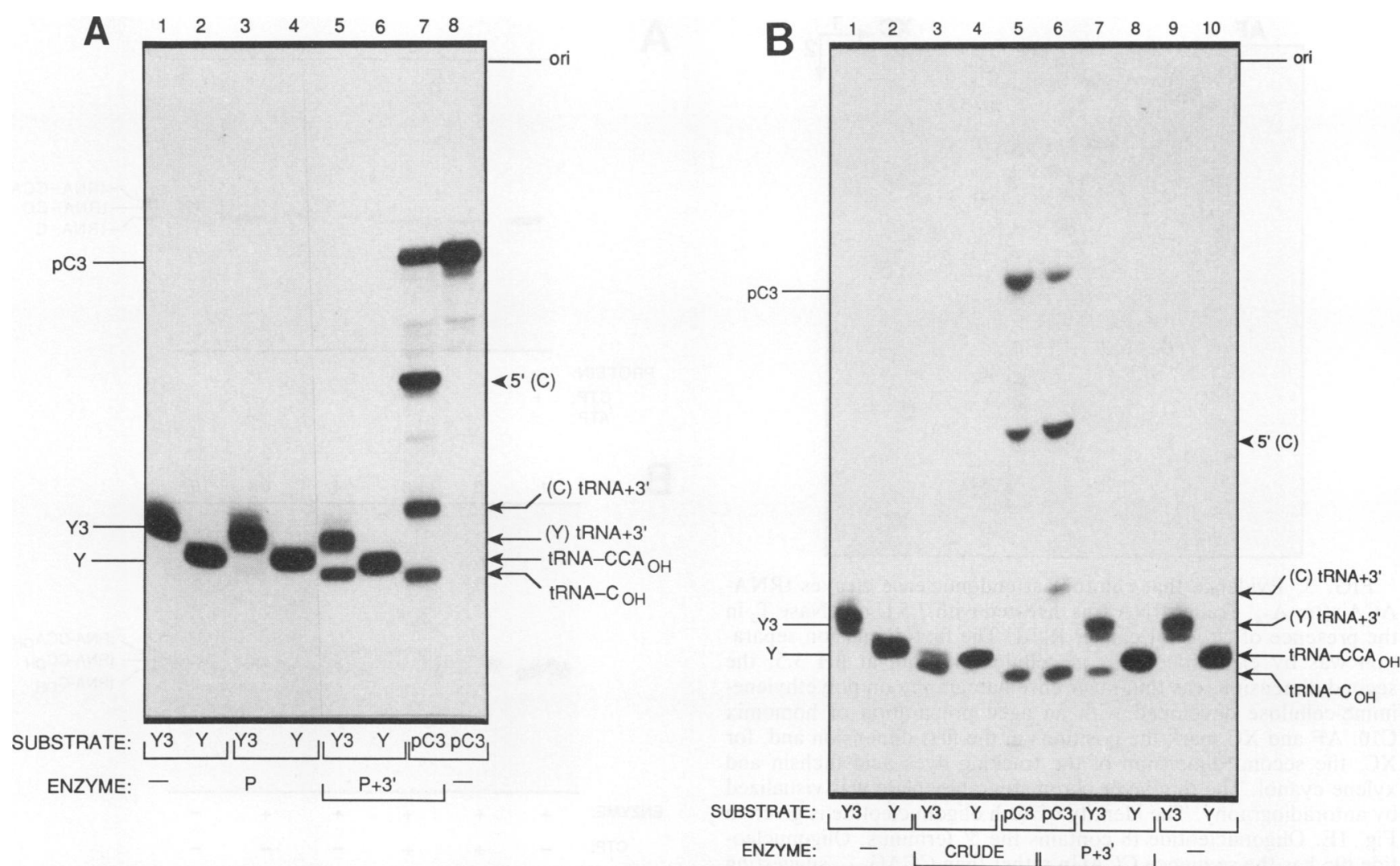

FIG. 2. Evidence that chloroplast endonuclease cleaves transfer RNAs after $\mathrm{C}_{74}$. Processing reactions were performed as described in Materials and Methods. The substrates indicated at the bottom and on the left are designated pC3 $\left(5^{\prime}\right.$--, $3^{\prime}$-extended chloroplast pre-tRNA ${ }^{\text {Phe }}$ transcripts of BamHI-linearized pNBPhe), Y3 (5'-mature, 3'-extended yeast tRNA ${ }^{\text {Phe }}$ transcripts of BamHI-cut p67YF0), and Y (5'-, $3^{\prime}$-mature transcripts of Bst NI-cleaved p67YF0). Enzyme sources indicated at the bottom are crude (fraction II) and P+3' (fraction C, containing RNase $\mathrm{P}$ plus $3^{\prime}$ cleavage activities). Indicated along the right are the positions of cleavage products: $(C)$ and $(\mathrm{Y})$ designate chloroplast and yeast tRNA-specific products, respectively; $5^{\prime}$ indicates the $5^{\prime}$ leader; and tRNA+3' refers to the covalent tRNA-trailer species. Mature tRNA is labeled tRNA-CCA $\mathrm{OH}_{\text {. }}$ (A) Processing with fraction C chloroplast enzymes; (B) comparison of fraction II and fraction $\mathrm{C}$ activities.

previously characterized side reaction of tRNA nucleotidyltransferases which can occur in the absence of CTP [9]). The lower efficiency of AMP addition is consistent with the observation that measured $K_{m}$ 's of most tRNA nucleotidyltransferases for ATP are much higher than their $K_{m}$ 's for CTP (9). In these experiments, CTP was in excess whereas ATP was limiting.

Cleavage when nucleotide 74 is not cytidylate. Knowing that two tRNA-C ${ }_{74} \mathrm{~N}_{75} \mathrm{~N}_{76}$-species, tRNA-CCA-trailer and tRNACAG-trailer, are cleaved between $\mathrm{C}_{74}$ and $\mathrm{N}_{75}$, we next sought to establish the site of cleavage on substrates containing a base other than $C$ at position 74 . The most likely possibility is that another endonuclease activity would cut after base 73, or that cleavage would still occur after base 74, followed by exonucleolytic removal of that base. To test these possibilities, we determined the cleavage site of a $3^{\prime}$-extended yeast pre-tRNA ${ }^{\text {Phe }}$ in which $C_{74}$ had been replaced with $A$ as described in Materials and Methods. Pre-tRNA substrate tRNA-ACA-trailer, transcribed from plasmid pUC19-YF0A74/PvuII, was processed with a crude chloroplast enzyme preparation, and the $3^{\prime}$ trailer fragment was recovered by denaturing polyacrylamide gel electrophoresis. The trailer RNA was analyzed by two-dimensional fingerprinting of RNase $T_{1}$-generated oligonucleotides, as shown in Fig. 3. The sequence composition of each oligonu- cleotide $>4$ nt was established by redigestion with RNase A. The identity and origin of each oligonucleotide are shown in Fig. 1E. The molar yield of each oligonucleotide was within 10 to $25 \%$ of theoretical values except for the three largest species (t18 to t20), which were recovered at 0.6 to $0.7 \mathrm{~mol}$. The candidate $5^{\prime}$ terminus, $t 8$, and neighboring oligonucleotides were also redigested with RNase $T_{2}$. Details are provided in Materials and Methods. Oligonucleotide $\mathbf{t} 8$ has the composition pCp $+\mathrm{ApGp}$ (RNase A) and $\mathrm{pCp}+\mathrm{Ap} / \mathrm{Gp}$ (RNase $T_{2}$ ) and thus has the sequence pCpApGp, corresponding to nucleotides 75 to 77 of the pre-tRNA. This sequence is generated by endonucleolytic cleavage $5^{\prime}$ to the phosphodiester phosphate joining nucleotides $A_{74}$ and $C_{75}$. Cleavage of tRNA-ACA-trailer thus occurs at precisely the same position as does cleavage of tRNA-CCA-trailer or tRNA-CAG-trailer. If cleavage had occurred between $\mathbf{A}_{73}$ and $A_{74}$, according to our alternate prediction, the $3^{\prime}$ trailer would have had a 5'-terminal RNase $T_{1}$ product $\mathrm{pApC}$ pApGp. We did not detect in $\mathbf{t} 8$ or in other oligonucleotides either the RNase A product $\mathrm{pApCp}$ or the RNase $\mathrm{T}_{2}$ product pAp, which would have arisen from the sequence pACAGp. Because oligonucleotide $t 8$ was recovered at $0.9 \mathrm{~mol} / \mathrm{mol}$ of trailer RNA (equal to $1 \mathrm{~mol} / \mathrm{mol}$ within experimental error), it is unlikely that any other $5^{\prime}$ end was also present in significant amounts. 


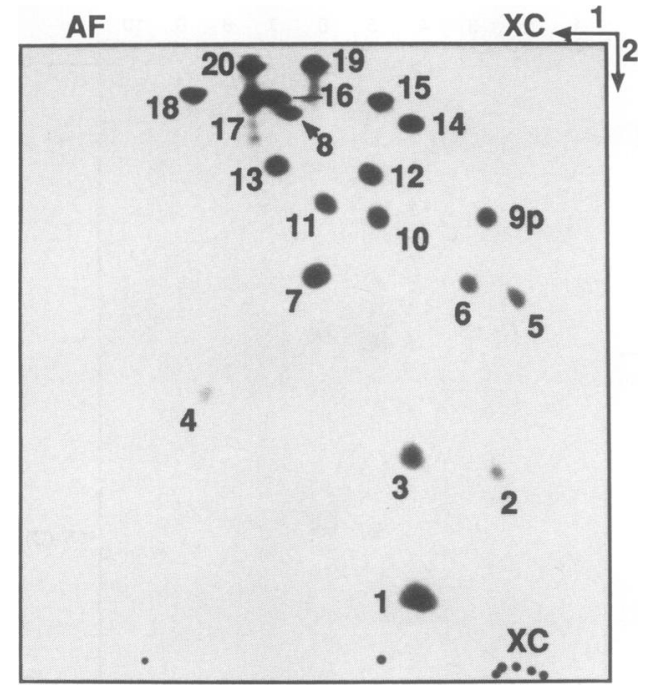

FIG. 3. Evidence that chloroplast endonuclease cleaves tRNAACA after $A_{74}$. Trailer RNA was digested with $7.5 \mathrm{U}$ of RNase $T_{1}$ in the presence of $20 \mu \mathrm{g}$ of carrier RNA. The first-dimension separation was by electrophoresis on cellulose acetate at $\mathrm{pH} 3.5$; the second dimension was thin-layer chromatography on polyethyleneimine-cellulose developed with an aged preparation of homomix $\mathrm{C} 10$. AF and XC mark the positions in the first dimension and, for $\mathrm{XC}$, the second dimension of the tracking dyes acid fuchsin and xylene cyanol. The thin-layer chromatography plate was visualized by autoradiography. The identity of each oligonucleotide is given in Fig. 1E. Oligonucleotide $t 8$ contains the 5 ' terminus. Oligonucleotide $t 9 p$ has the sequence $C C A G p$ rather than $\mathrm{CCAG}_{\mathrm{OH}}$, suggesting that the trailer RNA terminated with ...CCAGpN $\mathrm{OH}_{\mathrm{OH}}$ (37).

tRNA 3 '-terminal maturation by a wheat embryo activity. Previously described nuclear 3 '-processing activities from several organisms except the yeast $S$. cerevisiae all cleaved their substrates between bases 73 and 74 of the mature tRNA domain. In contrast, the $S$. cerevisiae 3 '-processing enzyme is an exonuclease $(12,33)$. We were curious to learn whether plant nuclear tRNA 3'-processing activity was exo- or endonucleolytic and, if it was endonucleolytic, whether it would cleave at the same site as the other nuclear activities or at the site chosen by the chloroplast enzyme. We also considered the possibility that isoforms of the same endonuclease could be present both in the nucleus/cytoplasm and in the chloroplast. To test this idea, we assayed 3 '-extended yeast pretRNA ${ }^{\text {Phe }}$ transcripts with a partially purified preparation of $5^{\prime}$ and $3^{\prime}$ maturation activities from wheat embryo. Because initial trials indicated that $5^{\prime}$-mature, $3^{\prime}$-extended pre-tRNAs were not processed by this enzyme preparation (data not shown), we used for these experiments precursors which were $5^{\prime}$ and $3^{\prime}$ extended.

Figure 5 shows a comparison of these substrates processed in parallel with either spinach chloroplast or wheat embryo fractions. The $5^{\prime}$-extended, $3^{\prime}$-mature substrate $\mathrm{pY}$ (pre-tRNA-CCA $\mathrm{OH}_{\mathrm{OH}}$ ) was processed at its $5^{\prime}$ side by RNase $\mathrm{P}$ from wheat embryo (lane 5) or chloroplast (lane 4) to a species coelectrophoresing with mature tRNA-CCA $\mathrm{OH}_{\mathrm{OH}}$ (lane 6). No trimming at the $3^{\prime}$ side was detected. In contrast, precursor pY3B (pre-tRNA-CCA-trailer) with an 8-nt-long 3' extension was processed to a species 73 to $74 \mathrm{nt}$ long by the combined action of RNase P plus $3^{\prime}$ nuclease in wheat or chloroplast fractions (lanes 7 and 8). The same product was generated with wheat or chloroplast activities from the

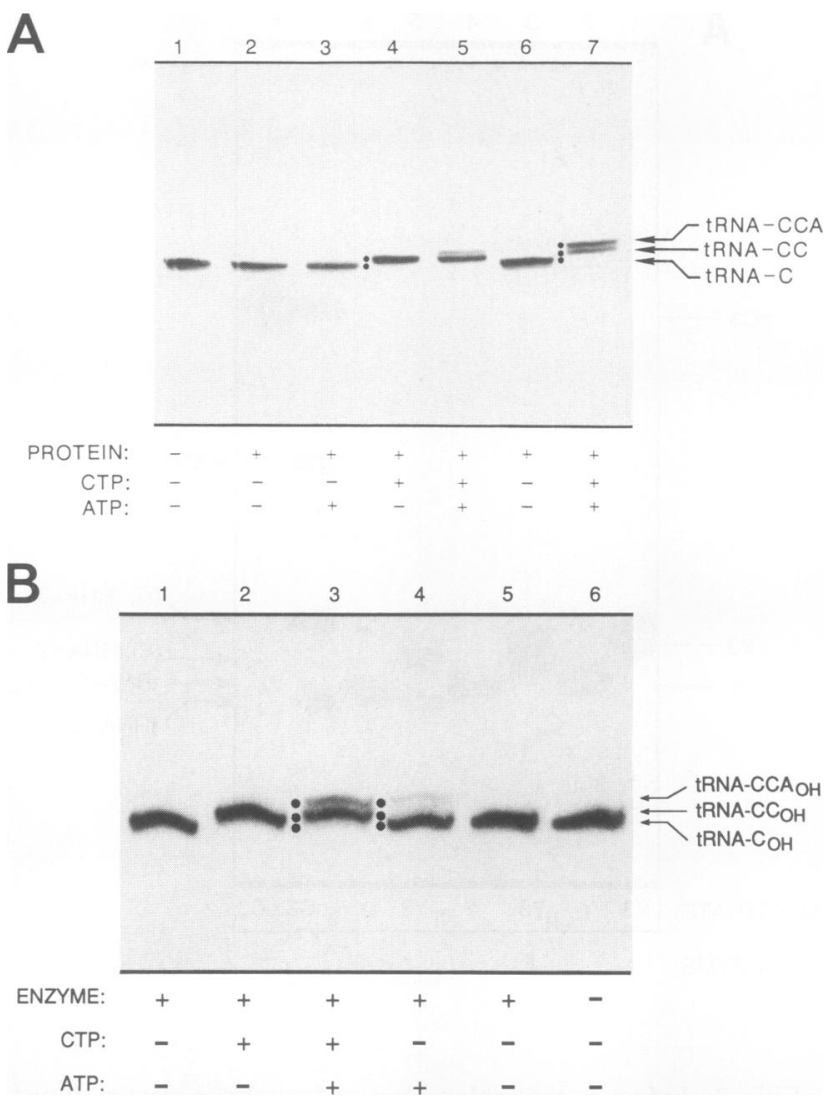

FIG. 4. Completion of the CCA terminus by stepwise C-A addition. Yeast tRNA ${ }^{\text {Phe }}$, cleaved at its $3^{\prime}$ end in a preparative-scale reaction with chloroplast fraction II protein, was isolated and reincubated with fraction II as a source of tRNA nucleotidyltransferase (enzyme) and CTP or ATP as indicated at the bottom. Details are given in the text. (A) C-A addition to chloroplast tRNA ${ }^{\text {Phe }}-\mathrm{C}_{\mathrm{OH}}$. One preparation of fraction II protein was used in lanes 2 to 5 , and another was used in lanes 6 and 7. (B) C-A addition to yeast tRNA $^{\text {Phe }}-\mathrm{C}_{\mathrm{OH}}$.

corresponding precursor with a 35-nt $3^{\prime}$ extension, pY3H (lanes 10 and 11).

The site of 3 ' cleavage by the wheat embryo activity was mapped precisely by repairing the product with tRNA nucleotidyltransferase. Processed tRNA, from a preparative reaction like that of Fig. 5, lane 11, was eluted and incubated with crude chloroplast nucleotidyltransferase as used in Fig. 4. The extent of repair was judged by gel electrophoresis. Figure 6 shows that in the presence of CTP alone (lane 4), two bases were added, and in the presence of CTP plus ATP (lane 5), three nucleotides were filled in to generate $3^{\prime}$ mature tRNA-CCA $\mathrm{OH}_{\mathrm{OH}}$. Again, little addition occurs in the presence only of ATP (lane 3 ). This result demonstrates that the wheat embryo nuclease cleaved pre-tRNA after nucleotide 73 .

\section{DISCUSSION}

Substrate recognition for terminal maturation. These results provide a clear demonstration of the recognition specificity of tRNA 3 ' cleavage activities from spinach chloroplasts and from wheat embryo on precursor tRNAs possessing all or part of the 3' CCA sequence. The chloroplast activity consistently generates tRNAs terminated after 


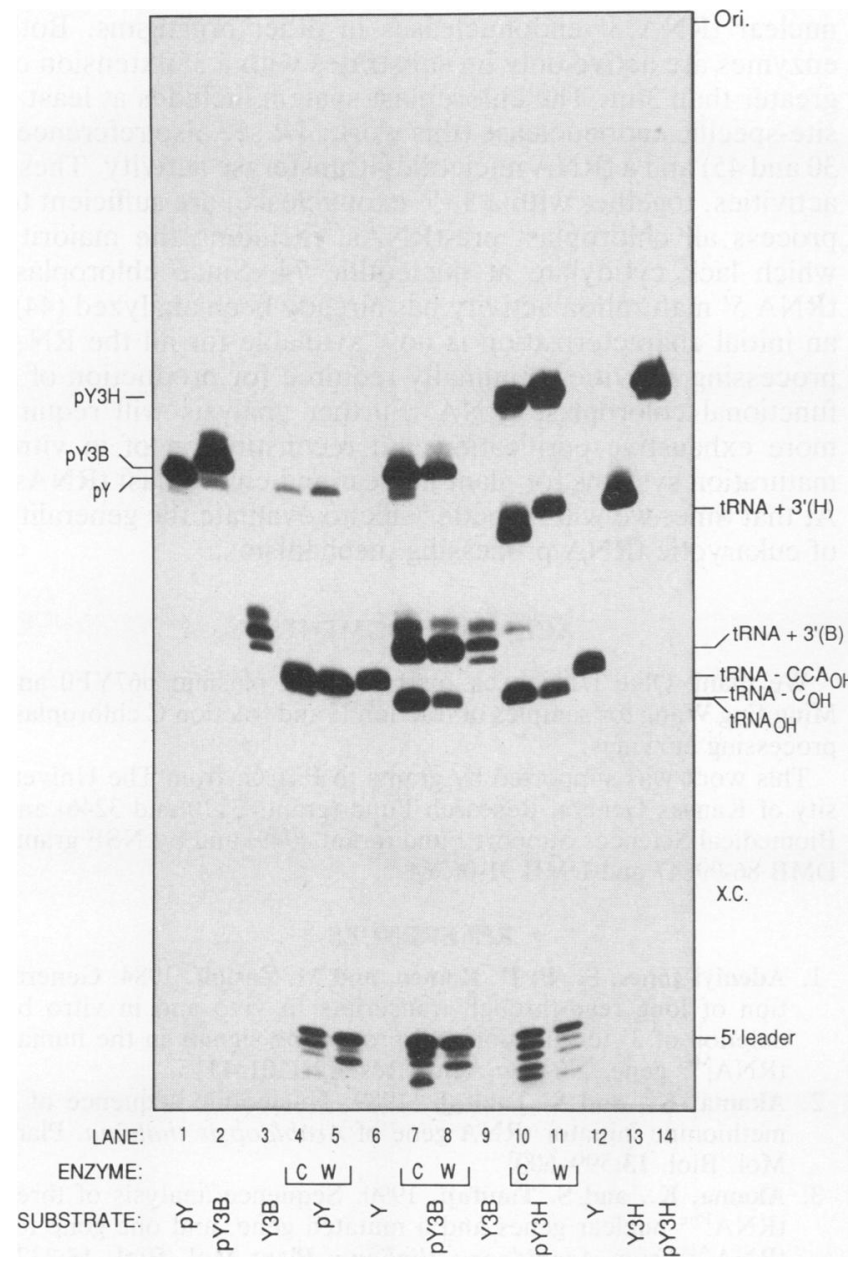

FIG. 5. tRNA $3^{\prime}$ cleavage by wheat embryo nuclease. Three $5^{\prime}$-extended yeast pre-tRNA ${ }^{\text {Phe }}$ substrates whose structures are shown in Fig. 1 were used. The substrates all had the same 38 -nt-long $5^{\prime}$ extension. Substrate pY (lanes 1,4 , and 5) is $3^{\prime}$ mature; pY3B (lanes 2, 7, and 8) has an 8-nt $3^{\prime}$ extension including the CCA, and substrate pY3H (lanes 10,11 , and 14) has a 35-nt $3^{\prime}$ extension including the CCA. Processing reactions were performed with enzymes from chloroplast (fraction $C$ ) (C; lanes 4, 7, and 10) and from wheat embryo (HA-Ultrogel pool) (W; lanes 5, 8, and 11). As markers for the $5^{\prime}$-mature, $3^{\prime}$-extended processing intermediates generated by RNase P cleavage, we used $5^{\prime}$-mature in vitro transcripts corresponding to each 5 '-, 3'-extended pre-tRNA substrate. These are indicated as $Y$ in lanes 6 and 12, Y3B in lanes 3 and 9, and $\mathrm{Y} 3 \mathrm{H}$ in lane 13. The central band of RNA Y3B is the correct-size runoff transcript. X.C., xylene cyanol.

nucleotide 74 even when a complete $\mathrm{CCA}_{74-76}$ sequence is present in the precursor, when the CCA sequence is reduced as in tRNA-CAG-trailer, or when it is interrupted as in tRNA-ACA-trailer. Thus, these terminal maturation systems do not recognize (and retain) the CCA sequence per se. The recognition pattern of chloroplast endonuclease may reflect the distribution of sequences at the $3^{\prime}$ end of chloroplast tRNA genes: approximately one-fifth of 169 sequenced tRNA genes encodes $C_{74}$, but only seven also contain $C_{75}$, and only one gene codes for the entire $\mathrm{CCA}_{74-76}$ domain. Conceivably, it is parsimonious for the $3^{\prime}$ maturation system to retain $C_{74}$, but there is little advantage in recognizing $C_{75}$ and/or $A_{76}$. On the basis of these observations, we predict that chloroplast precursors to tRNA $\mathrm{UGG}_{\mathrm{UGO}}^{\text {Pro }}$ (trailed by $\mathrm{CC}$ ) and

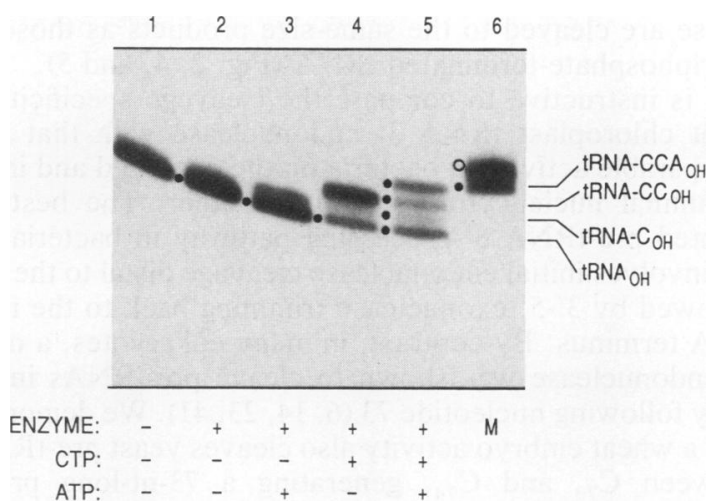

FIG. 6. Evidence that the 3' terminus of wheat embryo-cleaved tRNA is filled in by CCA. Processed yeast tRNA ${ }^{\text {Phe }}$ from a reaction with wheat embryo enzymes, as in Fig. 5, lane 11, was incubated with chloroplast fraction II as a source of nucleotidyltransferase activity. CTP was added to $0.1 \mathrm{mM}$ in lanes 4 and 5, and ATP was present at $1.0 \mathrm{mM}$ in lanes 3 and 5 . Lane 1 is an unincubated control. Lane 6 is a marker for $3^{\prime}$-mature tRNA ${ }^{\text {Phe }}$; the lower band is the CCA-containing runoff transcript. (The upper band contains nontemplate-specific bases added by T7 RNA polymerase [37].)

to wheat tRNA Gly (followed by CCA) are all processed by cleavage between the first and second $C$. In contrast, the 3 '-processing activity from wheat embryo, presumably nuclear or cytoplasmic in origin, can cleave its substrate after nucleotide 73 and remove an entire CCA sequence.

If the mature CCA terminus is not recognized per se, how are these 3 '-terminal maturation systems precluded from counterproductively processing an already mature tRNA and removing part of its CCA sequence? The answer appears to be that plant 3'-processing nucleases are specific for substrates possessing a 3 '-terminal extension extending past nucleotide 76. We found that mature tRNA ${ }^{\text {Phe }}-\mathrm{CCA}_{\mathrm{OH}}$ was not a substrate for $3^{\prime}$ cleavage; only pre-tRNA ${ }^{\text {Phe }}$ with an additional $3^{\prime}$ extension could be processed to mature tRNA.

Nucleolytic activities. The only characterized tRNA 3'processing activity in chloroplasts is currently the endonuclease which cleaves chloroplast or yeast tRNA ${ }^{\text {Phe }}$ after nucleotide 74 (this work; 44). We cannot exclude that other tRNAs may be processed by different activities. Maturation of tRNAs lacking $\mathrm{C}_{74}$ must include the participation of a $3^{\prime}-5^{\prime}$ exonuclease(s). We also cannot rule out the possibility that the wheat embryo activity is that of an exonuclease, although the lack of detectable reaction intermediates is more consistent with endonuclease cleavage. Further purification of the relevant enzymes will permit more definitive analysis of this point. Multiple tRNA 3' endonuclease activities have been reported in other organellar systems. Chen and Martin (7) separated from yeast mitochondria a major activity cleaving between nucleotides 73 and 74 from a minor activity cleaving between positions 76 and 77 . With partially purified rat liver mitochondrial enzyme, a CCA-containing $E$. coli pre-tRNA was cleaved both after positions 74 and 76 , although a combination of endo- plus exonuclease action was not ruled out (28).

The site of 3' cleavage by the chloroplast fraction does not appear to be artifactually influenced by the presence of a triphosphate rather than a monophosphate terminus on the pre-tRNA substrate. 5'-mature substrates (Y3B and $\mathrm{Y} 3 \mathrm{H}$ ) bear $5^{\prime}$ triphosphate termini and are cleaved at base 74 . 5 '-extended precursors (pY3B, pY3H, and pC3) are first processed by RNase $P$ to yield $5^{\prime}$ monophosphate termini. 
These are cleaved to the same-size products as those from 5 '-triphosphate-terminated tRNA (Fig. 2, 4, and 5).

It is instructive to compare the cleavage specificity of a plant chloroplast tRNA $3^{\prime}$ endonuclease with that of the comparable activity in bacteria on the one hand and in plant or animal nuclei/cytoplasm on the other. The best-documented pre-tRNA 3 '-processing pathway in bacteria $(4,8$, 39) involves initial endonuclease cleavage distal to the tRNA followed by $3^{\prime}-5^{\prime}$ exonuclease trimming back to the mature CCA terminus. By contrast, in many eukaryotes, a nuclear $3^{\prime}$ endonuclease was shown to cleave pre-tRNAs immediately following nucleotide $73(6,14,23,41)$. We demonstrate that a wheat embryo activity also cleaves yeast pre-tRNA ${ }^{\text {Phe }}$ between $\mathrm{C}_{73}$ and $\mathrm{C}_{74}$, generating a 73-nt-long product, tRNA $_{\mathrm{OH}}$. A spinach chloroplast enzyme, however, cuts the same pre-tRNA precisely between nucleotides 74 and 75 , leaving a 74-nt-long tRNA- $\mathrm{C}_{\mathrm{OH}}$. In plants, at least, it appears that although the nuclear and organellar tRNA 3'-processing enzymes process pre-tRNA at slightly different sites, the two tRNA 3' cleavage mechanisms resemble each other more than either does the best-described bacterial pathway.

Maturation pathways. (i) Chloroplast. tRNA 3'-terminal maturation in spinach chloroplasts follows the general pathway of other nuclear and organellar systems. Both in animal nuclei and in animal and fungal mitochondria, $3^{\prime}$ cleavage generally follows $5^{\prime}$ processing. Where examined, $3^{\prime}$ endonucleases have always exhibited a clear preference for 5 '-mature substrates. We previously found that $5^{\prime}$-mature, $3^{\prime}$-extended chloroplast tRNA ${ }^{\text {Phe }}$ was an effective substrate for further $3^{\prime}$ maturation (44). Alternate processing pathways have also been observed $(30,36)$, and it was proposed that the order of $5^{\prime}$ and $3^{\prime}$ processing in vivo may be governed by kinetic rather than by mechanistic considerations (7).

(ii) Nucleus/cytoplasm. The order of $5^{\prime}$ and $3^{\prime}$ cleavage in the wheat embryo system is currently unresolved. Our current data are consistent with a model in which 5 '- and 3 '-processing events are cooperative. The evidence is that (i) $5^{\prime}$-mature, $3^{\prime}$-extended in vitro transcripts (Y3B or $\left.\mathrm{Y} 3 \mathrm{H}\right)$ are processed poorly or not at all at their $3^{\prime}$ ends by a preparation containing wheat embryo RNase P and low levels of $3^{\prime}$ nuclease activity (data not shown; 32a), whereas (ii) $5^{\prime}$ - and $3^{\prime}$-extended substrates (pY3B or pY3H) can be processed at both termini by the same enzyme fraction (Fig. 5). Further progress will require purified $3^{\prime}$ nuclease preparations.

CCA addition. These experiments used endogenous chloroplast CTP(ATP):tRNA nucleotidyltransferase activity to complete the maturation of tRNA precursors. By separating cleavage from nucleotide addition, we demonstrated the stepwise nature of CMP and AMP addition to processed tRNA termini. This is the first direct demonstration that chloroplast nucleotidyltransferase activity participates in tRNA maturation. In previous studies of chloroplast tRNA processing $(19,20,22,30)$, the presence of a CCA sequence had been inferred from electrophoretic mobility of maturesize tRNAs (30) or from the position of tRNA 3 '-terminal oligonucleotides in RNA fingerprint patterns (19).

Conclusion. This communication reports specifics of a tRNA $3^{\prime}$ maturation system from spinach chloroplasts which in cleavage specificity resembles, but is not identical to, that from several other nuclear and organellar sources. In addition, we have partially characterized a distinct 3 ' nuclease activity from wheat embryo which can participate in maturation of nuclear tRNAs. The chloroplast endonuclease cuts at a novel position $1 \mathrm{nt}$ past the $3^{\prime}$ end of the mature tRNA domain. In contrast to the chloroplast enzyme, the wheat embryo activity cleaves at the same position reported for nuclear tRNA $3^{\prime}$ endonucleases in other organisms. Both enzymes are active only on substrates with a $3^{\prime}$ extension of greater than $3 \mathrm{nt}$. The chloroplast system includes at least a site-specific endonuclease (this work; 44 ; see also references 30 and 45) and a tRNA nucleotidyltransferase activity. These activities, together with a $3^{\prime}-5^{\prime}$ exonuclease, are sufficient to process all chloroplast pre-tRNAs, including the majority which lack cytidylate at nucleotide 74 . Since chloroplast tRNA 5' maturation activity has already been analyzed (44), an initial characterization is now available for all the RNA processing activities minimally required for production of a functional chloroplast tRNA. Further analysis will require more exhaustive purification and reconstitution of in vitro maturation systems for plant nuclear and chloroplast tRNAs. At that time, we will be better able to evaluate the generality of eukaryotic tRNA processing mechanisms.

\section{ACKNOWLEDGMENTS}

We thank Olke Uhlenbeck for his gift of plasmid p67YF0 and Ming Jing Wang for samples of fraction II and fraction C chloroplast processing enzymes.

This work was supported by grants to P.A.G. from The University of Kansas General Research Fund (grants 3110 and 3246) and Biomedical Sciences Support Fund (grant 4949) and by NSF grants DMB 86-09647 and DMB 91-06364.

\section{REFERENCES}

1. Adeniyi-Jones, S., P. H. Romeo, and M. Zasloff. 1984. Generation of long read-through transcripts in vivo and in vitro by deletion of $3^{\prime}$ termination and processing signals in the human tRNA $_{i}^{\text {Met }}$ gene. Nucleic Acids Res. 12:1101-1115.

2. Akama, K., and S. Tanifuji. 1989. Nucleotide sequence of a methionine initiator tRNA gene of Arabidopsis thaliana. Plant Mol. Biol. 13:599-600.

3. Akama, K., and S. Tanifuji. 1990. Sequence analysis of three $\mathrm{tRNA}^{\text {Phe }}$ nuclear genes and a mutated gene, and one gene for tRNA $^{\text {Ala }}$ from Arabidopsis thaliana. Plant Mol. Biol. 15:337346.

4. Bikoff, E. K., B. F. LaRue, and M. L. Gefter. 1975. In vitro synthesis of transfer RNA. II. Identification of required enzymatic activities. J. Biol. Chem. 250:6248-6255.

5. Canaday, J., P. Guillemaut, R. Gloeckler, and J.-H. Weil. 1980. Comparison of the nucleotide sequences of chloroplast tRNAs ${ }^{\text {Phe }}$ and tRNAs ${ }_{3}^{\text {Leu }}$ from spinach and bean. Plant Sci. Lett. 20:57-62.

6. Castaño, J. G., Tobian, J. A., and M. Zasloff. 1985. Purification and characterization of an endonuclease from Xenopus laevis ovaries which accurately processes the $3^{\prime}$ terminus of human pre-tRNA ${ }_{i}^{\text {Met }}$ (3' pre-tRNase). J. Biol. Chem. 260:9002-9008.

7. Chen, J.-Y., and N. C. Martin. 1988. Biosynthesis of tRNA in yeast mitochondria. An endonuclease is responsible for the 3'-processing of tRNA precursors. J. Biol. Chem. 263:1367713682.

8. Cudny, H., and M. P. Deutscher. 1980. Apparent involvement of ribonuclease $D$ in the $3^{\prime}$ processing of tRNA precursors. Proc. Natl. Acad. Sci. USA 77:837-841.

9. Deutscher, M. P. 1982. tRNA nucleotidyltransferase, p. 183215. In P. D. Boyer (ed.), The enzymes, vol. XV. Academic Press, New York.

10. Deutscher, M. P. 1983. tRNA nucleotidyltransferase and the -C-C-A terminus of transfer RNA, p. 159-183. In S. T. Jacob (ed.), Enzymes of nucleic acid synthesis and modification, vol. II. CRC Press, Boca Raton, Fla.

11. Deutscher, M. P. 1984. Processing of tRNA in prokaryotes and eukaryotes. Crit. Rev. Biochem. 17:45-71.

12. Engelke, D. R., P. Gegenheimer, and J. Abelson. 1985. Nucleolytic processing of a tRNA ${ }^{\text {Arg }}$-tRNA ${ }^{\text {Asp }}$ dimeric precursor by a homologous component from Saccharomyces cerevisiae. J. Biol. Chem. 260:1271-1279.

13. Fournier, M. J., and H. Ozeki. 1985. Structure and organization of the transfer ribonucleic acid genes of Escherichia coli K-12. 
Microbiol. Rev. 49:379-397.

14. Frendewey, D., T. Dingerman, L. Cooley, and D. Söll. 1985. Processing of precursor tRNAs in Drosophila. Processing of the $3^{\prime}$ end involves an endonucleolytic cleavage and occurs after 5 ' end maturation. J. Biol. Chem. 260:449-454.

15. Garber, R. L., and S. Altman. 1979. In vitro processing of $B$. mori transfer RNA precursor molecules. Cell 17:389-397.

16. Garber, R. L., and L. P. Gage. 1979. Transcription of a cloned Bombyx mori tRNA ${ }_{2}^{\mathrm{Ala}}$ gene: nucleotide sequence of the tRNA precursor and its processing in vitro. Cell 18:817-828.

17. Gegenheimer, P. 1990. Preparation of extracts from plants. Methods Enzymol. 182:174-193.

18. Gegenheimer, P., and D. Apirion. 1981. Processing of procaryotic ribonucleic acids. Microbiol. Rev. 45:502-541.

19. Greenberg, B. M., W. Gruissem, and R. B. Hallick. 1984. Accurate processing and pseudouridylation of chloroplast transfer RNA in a chloroplast transcription system. Plant Mol. Biol. 3:97-109.

20. Greenberg, B. M., and R. B. Hallick. 1986. Accurate transcription and processing of 19 Euglena chloroplast tRNAs in a Euglena soluble extract. Plant Mol. Biol. 6:89-100.

21. Gruissem, W., B. M. Greenberg, G. Zurawski, and R. B. Hallick. 1986. Chloroplast gene expression and promoter identification in chloroplast extracts. Methods Enzymol. 118:253270.

22. Gruissem, W., B. M. Greenberg, G. Zurawski, D. M. Prescott, and R. B. Hallick. 1983. Biosynthesis of chloroplast transfer RNA in a spinach chloroplast transcription system. Cell 35:815828.

23. Hagenbüchle, O., D. Larson, G. I. Hall, and K. U. Sprague. 1979. The primary transcription product of a silkworm alanine tRNA gene: identification of in vitro sites of initiation, termination, and processing. Cell 18:1217-1229.

24. Hallick, R. B., and W. Bottomley. 1983. Proposals for the naming of chloroplast genes. Plant Mol. Biol. Rep. 1:38-43.

25. Hiratsuka, J., H. Shimada, R. Whittier, T. Ishibashi, M. Sakamoto, M. Mori, C. Kondo, Y. Honji, C. R. Sun, B. Y. Meng, Y. Q. Ki, A. Kanno, Y. Nishizawa, A. Hirai, K. Shinozaki, and M. Sugiura. 1989. The complete sequence of the rice (Oryza sativa) chloroplast genome: intermolecular recombination between distinct tRNA genes accounts for a major plastid DNA inversion during the evolution of cereals. Mol. Gen. Genet. 217:185-194.

26. Hollingsworth, M. J., and N. C. Martin. 1986. RNase P activity in the mitochondria of Saccharomyces cerevisiae depends on both mitochondrion and nucleus-encoded components. Mol. Cell. Biol. 6:1058-1064.

27. King, T. C., R. Sirdeskmukh, and D. Schlessinger. 1986. Nucleolytic processing of ribonucleic acid transcripts in procaryotes. Microbiol. Rev. 50:428-451.

28. Manam, S., and G. C. Van Tuyle. 1987. Separation and characterization of 5' - and 3'-tRNA processing nucleases from rat liver mitochondria. J. Biol. Chem. 262:10272-10279.

29. Maniatis, T., E. F. Fritsch, and J. Sambrook. 1982. Molecular cloning: a laboratory manual, p. 88-89. Cold Spring Harbor Laboratory, Cold Spring Harbor, N.Y.

30. Marion-Poll, A., C. Hibbert, C. Radebaugh, and R. Hallick. 1988. Processing of mono-, di-, and tricistronic transfer RNAs precursors in a spinach or pea chloroplast soluble extract. Plant Mol. Biol. 11:45-56.

31. Micard, D., M. L. Sobrier, J. L. Couderc, and B. Dastugue. 1985. Purification of RNA-free plasmid DNA using alkaline extraction followed by Ultrogel A2 column chromatography. Anal. Biochem. 148:121-126.

32. Ohyama, K., H. Fukuzawa, T. Kohchi, H. Shirai, T. Sano, S. Sano, K. Umesono, Y. Shiki, M. Takeuchi, Z. Chang, S.-i. Aota, H. Inokuchi, and H. Ozeki. 1986. Complete nucletide sequence of liverwort Marchantia polymorpha chloroplast DNA. Plant Mol. Biol. Rep. 4:149-175.

32a.Oommen, A. 1991. Ph.D. dissertation. University of Kansas, Lawrence.

33. Piper, P. W., and K. B. Sträby. 1989. Processing of transcripts of a dimeric tRNA gene in yeast uses the nuclease responsible for maturation of the $3^{\prime}$ termini upon $5 \mathrm{~S}$ and $37 \mathrm{~S}$ precursor rRNAs. FEBS Lett. 250:311-316.

34. Quigley, F., and J.-H. Weil. 1985. Organization and sequence of five tRNA genes and of an unidentified reading frame in the wheat chloroplast genome: evidence for gene rearrangements during the evolution of chloroplast genomes. Curr. Genet. 9:495-503.

35. Robertson, H. D., S. Altman, and J. D. Smith. 1972. Purification and properties of a specific Escherichia coli ribonuclease which cleaves a tyrosine transfer ribonucleic acid precursor. J. Biol. Chem. 247:5243-5251.

36. Rooney, R. J., and J. D. Harding. 1986. Processing of mammalian tRNA transcripts in vitro: different pre-tRNAs are processed along alternative pathways that contain a common ratelimiting step. Nucleic Acids Res. 14:4849-4864.

37. Sampson, J. R., and O. C. Uhlenbeck. 1988. Biochemical and physical characterization of an unmodified yeast phenylalanine transfer RNA transcribed in vitro. Proc. Natl. Acad. Sci. USA 85:1033-1037.

38. Schimmel, P. R., D. Söll, and J. N. Abelson. 1979. Proposed numbering system of nucleotides in tRNAs based on yeast tRNA $^{\text {Phe, }}$, p. 518-519. In P. R. Schimmel, D. Söll, and J. N. Abelson (ed.), Transfer RNA: structure, properties, and recognition. Cold Spring Harbor Laboratory, Cold Spring Harbor, N.Y.

39. Sekiya, T., R. Contreras, T. Takeya, and H. G. Khorana. 1979. Total synthesis of a tyrosine suppressor transfer RNA gene. XVII. Transcription, in vitro, of the synthetic gene and processing of the primary transcript to transfer RNA. J. Biol. Chem. 254:5802-5816.

40. Shinozaki, K., M. Ohme, M. Tanaka, T. Wakasugi, N. Hayashida, T. Matsubayasha, N. Zaita, J. Chunwongse, J. Obokata, K. Yamaguchi-Shinozaki, C. Ohto, K. Torazawa, B. Y. Meng, M. Sugita, H. Deno, T. Kamogashira, K. Yamada, J. Kusuda, F. Takaiwa, A. Kato, N. Todoh, H. Shimada, and M. Sugiura. 1986. The complete nucleotide sequence of the tobacco chloroplast genome. Plant Mol. Biol. Rep. 4:111-147.

41. Solari, A., and M. P. Deutscher. 1983. Identification of multiple RNases in Xenopus laevis oocytes and their possible role in tRNA processing. Mol. Cell. Biol. 3:1711-1717.

42. Stange, N., H. J. Gross, and H. Beier. 1988. Wheat germ splicing endonuclease is highly specific for plant pre-tRNAs. EMBO J. 7:3823-3828

43. Steinmetz, A. A., E. T. Krebbers, Z. Schwartz, E. J. Gubbins, and L. Bogorad. 1983. Nucleotide sequence of five maize chloroplast transfer RNA genes and their flanking regions. J. Biol. Chem. 258:5503-5511.

44. Wang, M. J., N. W. Davis, and P. Gegenheimer. 1988. Novel mechanisms for maturation of chloroplast transfer RNA precursors. EMBO J. 7:1567-1574.

45. Yamaguchi-Shinozaki, K., K. Shinozaki, and M. Sugiura. 1987. Processing of precursor tRNAs in a chloroplast lysate: processing of the 5 ' end involves endonucleolytic cleavage by an RNase P-like enzyme and precedes $3^{\prime}$ end maturation. FEBS Lett. 215:131-136.

46. Zasloff, M., T. Santos, P. Romeo, and M. Rosenberg. 1982. Transcription and precursor processing of normal and mutant human tRNA $A_{i}^{\text {Met }}$ genes in a homologous cell-free system. J. Biol. Chem. 257:7857-7863.

47. Zhang, J. R., and M. P. Deutscher. 1988. Transfer RNA is a substrate for RNase D in vivo. J. Biol. Chem. 263:17909-17912. 